\title{
THE RELATIONSHIP AMONG SELF CONFIDENCE, LEARNING DISCIPLINE, AND USE OF LEARNING RESOURCES WITH MATHEMATICS LEARNING OUTCOMES IN STUDENTS CLASS VIII OF MTSN YOGYAKARTA II
}

\author{
Syah Fathi Azzatia ${ }^{a}$, Abdul Taram ${ }^{b}$ \\ Program Studi Pendidikan Matematika Universitas Ahmad Dahlan \\ Jalan Ringroad Selatan, Tamanan, Banguntapan, Bantul, Yogyakarta \\ aazzatia05@gmail.com, btaromahmad@yahoo.com
}

\begin{abstract}
Low of student mathematics learning outcomes are related to several factors. Self Confidence, learning discipline, and use of learning resources is some of the factors related to learning outcomes. This research aims to determine the presence or absence of a positive and significant relationship among confidence, learning discipline, and use of learning resources with mathematics learning outcomes in students class VIII of even Semester of MTsN Yogyakarta II in the academic year of 2015/2016. The population in this study was the girl students of grade VIII in MTsN Yogyakarta II in the academic year of 2015/2016, which was divided into 4 classes, namely VIII D, VIII E, VIII F, VIII G totaling 137 students. Samples were taken in class VIII E as research class sample and with random sampling technique to the class. Data was collected by questionnaire and test method. The research instrument were validity test, different power test, and reliability test. Test requirement analysis includes test of normality, linearity, and the independence. Analysis of the data for testing hypothesis using correlation and linear regression analysis. The results showed that there was a positive and significant relationship among self confidence, learning discipline, and use of learning resources with mathematics learning outcomes students of class VIII of even Semester in MTsN Yogyakarta II in the academic year of 2015/2016. It was showed by $\mathrm{F}_{\text {count }}=3.7896>\mathrm{F}_{\text {table }}=2.9011$ with $\mathrm{R}$ $=0.511998$ and $\mathrm{R}^{2}=0.2621$ with $\hat{Y}=-34.79089+0.35715 X_{1}+0.18246 X_{2}+0.45598 X_{3}$, with SR $\mathrm{X}_{1}=30.7344 \%, \quad \mathrm{SR} \quad \mathrm{X}_{2}=18.5067 \%$, and $\mathrm{SR} \quad \mathrm{X}_{3}=50.75895 \%, \mathrm{SE} \quad \mathrm{X}_{1}=8.056769796 \%, \quad \mathrm{SE}$ $\mathrm{X}_{2}=4.851375128 \%$ and SE $\mathrm{X}_{3}=13.3060524 \%$.
\end{abstract}

Keywords: Self Confidence, Learning Discipline, Use of Learning Resources, Mathematics Learning Outcomes.

\section{INTRODUCTION}

The development of the modern world has progressed very rapidly, demanding that everyone adapt, work hard to achieve the quality of life goals that are being reported. To deal with this, it is necessary to improve the quality of Human Resources by forming reliable, creative and innovative human beings. One way to improve the quality of human resources is to improve the quality of education, in the development of the world mathematics education is one of the important lessons, because in practice real life mathematics is used as a science of logical considerations in decision making. However, currently there are still some students who think that mathematics is a difficult lesson, has many complicated formulas, and seems boring to learn. So that students are reluctant to learn mathematics, consequently the mathematics learning outcomes become less optimal. The information is obtained from data sources from the results of the MTsN II Yogyakarta which states that there are some students whose their learning outcome are still below the Minimum completeness Criteria (CCM) of 67.

Less optimal mathematics learning outcomes at MTsN II Yogyakarta are thought to be caused by several things including a lack of student confidence, lack of student discipline, and lack of utilization of learning resources by students. Based on this, this study takes several variables as internal factors that are 
possible related to student learning outcomes. These factors include self-confidence and discipline of learning, while external factors are the use of learning resources.

Self-confidence is one of the possible internal factors related to student learning outcomes. Selfconfidence is the basis of self-motivation to succeed. According to Hakim, Thursan (2005: 6) simple selfconfidence can be said as a person's belief in all aspects of his strengths and that belief makes him feel able to achieve various goals in his life, simply defined, the notion of self-confidence is a belief someone who can push someone to move forward in a better direction.

Learning discipline is also possible related to student learning outcomes. Discipline is one of the things that are very important and needed by every student. If discipline is developed and applied properly and consistently it will have a good impact on the life and behavior of students. According to Amri, Sofan (2013: 162) discipline is the attitude of someone who shows obedience to existing rules or regulations and is carried out with pleasure and self-awareness. According to Mulyati in Pamungkas (2013) discipline is obedience (to rules and order). In simple terms, the definition of learning discipline can be formulated as an attitude, behavior, and behavior that shows compliance and adherence to regulations that apply both at home and in schools that grow from within students themselves

Then, external factors that are possible related to student learning outcomes are the use of learning resources. According to Sanjaya, Vienna (2009: 12) learning resources are related to everything that allows students to gain learning experience. According to Mulyasa (2010: 48) learning resources can be formulated as everything that can provide convenience to students in obtaining information, knowledge, experience, and skills, in the teaching and learning process. In simple terms it can be formulated understanding the use of learning resources is an activity in the use of anything that can provide knowledge or information that can be used in the learning process.

The problems in this study are: 1) Mathematics subjects are still considered difficult by some students. 2) Students' confidence in mathematics is still low. 3) Discipline in student mathematics learning is still lacking. 4) The source of learning mathematics in schools is sufficient, but some students have not utilized learning resources optimally. 5) The mathematics learning outcomes of students in MTsN II Yogyakarta have not been optimal. The mathematics learning outcomes of some students are still below the CCM score.

The purpose of this study was to find out: 1) Whether or not there is a relationship between selfconfidence and mathematics learning outcomes 2) Whether or not there is a relationship between the discipline of learning and the mathematics learning outcomes. 3) Whether or not there is a relationship between the use of learning resources and the mathematics learning outcomes. 4) Whether or not there is a relationship between self-confidence and discipline of learning with the learning outcomes. 5) Whether or not there is a relationship between self-confidence and the use of learning resources with the mathematics learning outcomes. 6) Whether or not there is a relationship between disciplinary learning and the use of mathematics learning resources with the learning outcomes. 7) Whether there is a relationship between self-confidence, discipline of learning, and the use of learning resources with mathematics learning outcomes of students in class VIII of even semester of MTsN II Yogyakarta in the academic year of 2015/2016.

\section{METHODS}

This research is classified as quantitative research and includes the type of correlation research with a population of eighth grade female students of MTsN II Yogyaarta in academic year of 2015/2016 with totaling 137 students consisting of 4 classes namely class VIII D, VIII E, VIII F, and VIII G. Election female class as a population class due to the separation between male and female classes in MTsN II Yogyakarta. Sampling was carried out using sampling techniques for the class. The sample of this study was 36 students in class VIII E and class VIII F as a trial class. Data collection techniques used were the questionnaire and the test method. The questionnaire was used for variables of self-confidence, learning discipline, and the use 
of learning resources. While the test was used for the variable learning outcomes of mathematics. The test of the research instrument used was validity, different power, and reliability test. Then to test the analysis prerequisites used are normality, linearity, and independence test. Data analysis for hypothesis testing used correlation and linear regression analysis.

\section{RESULTS AND DISCUSSION}

\section{Prerequisite Test for Regression Analysis}

\section{a. Normality test}

The summary of normality results can be seen in table 1 .

Table 1. Summary of Normality Test Results

\begin{tabular}{|c|c|c|c|}
\hline Variable & $\chi_{\text {count }}^{\mathbf{2}}$ & $\chi_{\text {table }}^{\mathbf{2}}$ & Df \\
\hline $\mathrm{X}_{1}$ & 2.016 & 7.8147 & 3 \\
\hline $\mathrm{X}_{2}$ & 4.045 & 7.8147 & 3 \\
\hline $\mathrm{X}_{3}$ & 0.352 & 5.992 & 2 \\
\hline $\mathrm{Y}$ & 4.346 & 9.4877 & 4 \\
\hline
\end{tabular}

From the normality test at a significant level $5 \%$ seen $\chi_{\text {count }}^{2} \leq \chi_{\text {table }}^{2}$, this means that the distribution of data obtained in each variable is normal.

\section{b. Independent Test}

The summary of the results of independent tests can be seen in table 2 .

Table 2. Independent Test Result Summary

\begin{tabular}{|c|c|c|}
\hline Variable & $\boldsymbol{\chi}_{\text {count }}$ & \multicolumn{1}{c|}{$\boldsymbol{\chi}_{\text {table }}$} \\
\hline $\mathrm{X}_{1}$ and $\mathrm{X}_{2}$ & 25.626 & 37.652 \\
\hline $\mathrm{X}_{1}$ and $\mathrm{X}_{3}$ & 31.259 & 37.652 \\
\hline $\mathrm{X}_{2}$ and $\mathrm{X}_{3}$ & 18.664 & 37.652 \\
\hline
\end{tabular}

From an independent test at a significant level $5 \%(\alpha=0.05)$ and the degree of freedom $(\mathrm{df})=(\mathrm{B}-$ $1)(\mathrm{K}-1)$ terlihat $\chi_{\text {count }}^{2} \leq \chi_{\text {table }}^{2}$, this means that the data obtained from each variable is independent.

\section{c. Linearity Test}

The summary results of the linearity test can be seen in table 3 .

Table 3. Summary of Linearity Test Results

\begin{tabular}{|c|c|c|}
\hline Variable & $F_{\text {count }}$ & $F_{\text {table }}$ \\
\hline $\mathrm{X}_{1}$ to $\mathrm{Y}$ & 0.1193 & 2.45 \\
\hline $\mathrm{X}_{2}$ to $\mathrm{Y}$ & 0.9099 & 2.27 \\
\hline $\mathrm{X}_{3}$ to $\mathrm{Y}$ & 1.4930 & 2.25 \\
\hline
\end{tabular}

From an independent test at a significant level $5 \%(\alpha=0.05)$ and the degree of freedom of the numerator $v_{1}=k-2$ dthe degree of freedom of the denominator $v_{2}=N-k$, seen $F_{\text {count }} \leq F_{\text {table }}$, this means that the data obtained from each variable is linear. 


\section{Hypothesis Testing}

\section{a. The First Hypothesis}

From the first hypothesis test at a significant level of $5 \%$ and $\mathrm{df}=34$ it can be seen that $t_{\text {count }}=2.0920 t_{\text {table }}=1.6909$ so $t_{\text {count }}>t_{\text {table }}$ which means there is a positive and significant relationship between self-confidence and mathematics learning outcomes of students in class VIII of MTsN II Yogyakarta in even semester in the academic year of 2015/2016.

In the first hypothesis test a simple correlation coefficient (r) of 0.3377 is obtained which means the relationship between self-confidence and mathematics learning outcomes has a weak relationship. Determinant coefficient $\left(r^{2}\right)$ of 0.11404 is obtained which can be explained that $11.404 \%$ of learning outcomes are influenced by self-confidence while the rest are influenced by other factors. The variation in mathematics learning outcomes $(\mathrm{Y})$ is explained by self-confidence $\left(X_{1}\right)$ through linear lines $\hat{Y}=11.85971186+0.505545191 \mathrm{X}_{1}$.

\section{b. Second Hypothesis}

From the second hypothesis test at a significant level of 5\% and $\mathrm{df}=34$, it can be seen that

$t_{\text {count }}=2.4208 t_{\text {table }}=1.6909$ so $t_{\text {count }}>t_{\text {table }}$ which means there is a positive and significant relationship between learning discipline and the mathematics learning outcomes of students in class VIII of MTsN II Yogyakarta in even semester in the academic year of 2015/2016. In the second hypothesis test obtained a correlation coefficient $(r) 0.3834$ which means the relationship between learning discipline with mathematics learning outcomes has a weak relationship. Obtained a determinant coefficient $\left(r^{2}\right)$ of 0.1470 which can be explained that $14.70 \%$ learning outcomes are influenced by learning discipline while the rest are influenced by other factors. The variation in mathematics learning outcomes $(Y)$ is explained by learning discipline $\left(X_{2}\right)$ through the linear line $\hat{Y}=3.494255195+0.55295849 \mathrm{X}_{2}$

\section{c. Third hypothesis}

From the third hypothesis test at a significant level of $5 \%$ and $\mathrm{df}=34$, it can be seen that $t_{\text {count }}=2,6002 t_{\text {table }}=1.6909$ so $t_{\text {count }}>t_{\text {table }}$ which means there is a positive and significant relationship between the use of learning resources with mathematics learning outcomes of students in class VIII of MTsN II Yogyakarta in even semester in the academic year of 2015/2016. In the third hypothesis test obtained the correlation coefficient (r) of 0.4072 , which means the relationship between the use of learning resources with mathematics learning outcomes has a weak relationship. Determinant coefficient $\left(r^{2}\right)$ of 0.1658 is obtained which can be explained that $16.58 \%$ of learning outcomes are influenced by the use of learning resources while the rest are influenced by other factors. The variation in mathematics learning outcomes $(Y)$ is explained by the use of learning resources $\left(X_{3}\right)$ through a linear line $\hat{Y}=11.70210011+0.568410242 X_{3}$.

\section{d. Fourth Hypothesis}

From the fourth hypothesis test at a significant level of $5 \%$ dan $v_{1}$ numerator $=2$ and $v_{2}$ numerator $=33$ so that it can be obtained $F_{\text {count }}=3.5265$ and $F_{\text {table }}=3.2849$ so $F_{\text {count }}>F_{\text {table }}$ which means there is a positive and significant relationship between self-confidence and discipline learning with students' mathematics learning outcomes of students in class VIII of MTsN II Yogyakarta in even semester in the academic year of 2015/2016. From the multiple correlation analysis obtained the multiple correlation coefficient $(R)$ of 0.4196 which means the relationship between selfconfidence and discipline of learning with mathematics learning outcomes has a weak relationship. In this study also obtained the coefficient of determination $\left(R^{2}\right)$ of 0.1761 means that $17.61 \%$ of learning outcomes are influenced by self-confidence and discipline of learning while the rest is influenced by other factors. The variation in mathematics learning outcomes $(Y)$ can be explained by 
self-confidence $\left(\mathrm{X}_{1}\right)$ and learning discipline $\left(\mathrm{X}_{2}\right)$ through linear lines $\hat{Y}=-11.50682894+$ $0.293588482 \mathrm{X}_{1}+0.413198021 \mathrm{X}_{2}$.

\section{e. Fifth Hypothesis}

From the fourth hypothesis test at a significant level of $5 \%$ and $v_{1}$ numerator $=2$ and $v_{2}$ numerator $=33$ so that it can be obtained $F_{\text {count }}=5.5663$ and $F_{\text {table }}=3.2849$ so $F_{\text {count }}>F_{\text {table }}$ which means there is a positive and significant relationship between self-confidence and utilization of learning resources with learning outcomes mathematics of students in class VIII of MTsN II Yogyakarta in even semester in the academic year of 2015/2016

From the multiple correlation analysis obtained the multiple correlation coefficient $(R)$ of 0.522 which means that the relationship between self-confidence and learning resources with the learning outcomes of mathematics has a weak relationship. In this study also obtained the coefficient of determination $\left(R^{2}\right)$ of 0.2523 means that $25.23 \%$ of learning outcomes are influenced by selfconfidence and utilization of learning resources while the rest is influenced by other factors. There are variations in mathematics learning outcomes $(Y)$ which can be explained by self-confidence $\left(\mathrm{X}_{1}\right)$ and utilization of learning resources $\left(X_{3}\right)$ through linear lines $\widehat{Y}=-29.74345272+0.44278474 X_{1}+$ $0.52215136 X_{3}$.

\section{f. Sixth Hypothesis}

From the fourth hypothesis test at a significant level of 5\% and numerator $v_{1}$ numerator $=2$ and $v_{2}$ numerator $=33$, so that it can be obtained $F_{\text {count }}=4.6483$ and $F_{\text {table }}=3.2849$ so $F_{\text {count }}>$ $F_{\text {table }}$ which means there is a positive and significant relationship between learning discipline and the use of learning resources with mathematics learning outcome of students in class VIII of MTsN II Yogyakarta in even semester in the academic year of 2015/2016. From the multiple correlation analysis obtained by the multiple correlation coefficient $\mathrm{t}(R)$ of 0.4688 which means the relationship between learning discipline and learning resource use with mathematics learning outcomes has a weak relationship In this study also obtained the coefficient of determination $\left(R^{2}\right)$ of 0.2198 means $21.98 \%$ learning outcomes in influence by the discipline of learning and the use of learning resources while the rest is influenced by other factors. The variation in mathematics learning outcomes $(Y)$ which can be explained by learning discipline $\left(\mathrm{X}_{2}\right)$ and the use of learning resources $\left(\mathrm{X}_{3}\right)$ through linear lines $\widehat{Y}=-14.78861+0.37006044 X_{2}+0.41603837 X_{3}$.

\section{g. Seventh Hypothesis}

From the fourth hypothesis test at a significant level of 5\% and $v_{1}$ numerator $=2$ and $v_{2}$ numerator $=33$, so that it can be obtained $F_{\text {count }}=3.7896$ and $F_{\text {table }}=2.9011$ so $F_{\text {count }}>F_{\text {table }}$ which means there is a positive and significant relationship between self-confidence, learning discipline, and resource utilization study with mathematics learning outcomes of students in class VIII of MTsN II Yogyakarta in even semester in the academic year of 2015/2016. From the multiple correlation analysis, it was obtained that the multiple correlation coefficient $(R)$ was 0.511998 which means that the relationship between self-confidence, learning discipline, and learning resources with mathematics learning outcomes had a moderate relationship. In this study also obtained the coefficient of determination $\left(R^{2}\right)$ of 0.2621 . The variation in mathematics learning outcomes $(Y)$ can be explained by self-confidence $\left(\mathrm{X}_{1}\right)$, learning discipline $\left(\mathrm{X}_{2}\right)$, and utilization of learning resources $\left(X_{3}\right)$ through linear lines $\widehat{Y}=-34.79089+0.35715 X_{1}+0.18246 X_{2}+0.45598 X_{3}$.

\section{CONCLUSION}

Based on the results of research and discussion, conclusions can be drawn, namely:

a. There is a positive and significant relationship between self-confidence and mathematics learning outcomes of students in class VIII of MTsN II Yogyakarta in even semester in the academic year of 2015/2016. 
b. There is a positive and significant relationship between the discipline of learning and the mathematics learning outcomes of students in class VIII of MTsN II Yogyakarta in even semester in the academic year of 2015/2016.

c. There is a positive and significant relationship between the use of learning resources and the mathematics learning outcomes of students in class VIII of MTsN II Yogyakarta in even semester in the academic year of 2015/2016.

d. There is a positive and significant relationship between self-confidence and discipline of learning with the learning outcomes of students in class VIII of MTsN II Yogyakarta in even semester in the academic year of 2015/2016.

e. There is a positive and significant relationship between self-confidence and the use of learning resources with the mathematics learning outcomes of students in class VIII of MTsN II Yogyakarta in even semester in the academic year of 2015/2016.

f. There is a positive and significant relationship between the discipline of learning and the use of mathematics learning resources with the learning outcomes of students in class VIII of MTsN II Yogyakarta in even semester in the academic year of 2015/2016.

g. There is a positive and significant relationship between self-confidence, learning discipline, and utilization of learning resources with mathematics learning outcomes of students in class VIII of MTsN II Yogyakarta in even semester in the academic year of 2015/2016.

\section{REFERENCES}

Amri, Sofan. 2013. Pengembangan dan Model Pembelajaran dalam Kurikulum 2013. Jakarta: Prestasi Pustakarya.

Mulyasa.2010.Kurikulum Berbasis Kompetensi. Bandung: PT Remaja Rosdakarya.

Hakim, Thursan.2005.Mengatasi Rasa Tidak Percaya Diri.Jakarta : Puspa Swara.

Pamungkas, Restu Ragil. 2013. Pengaruh Kedisiplinan Belajar dan Lingkungan Keluarga Terhadap Prestasi

Belajar Siswa SMK Negeri 1 Yogyakarta. http://journal.student.uny.ac.id/jurnal/artikel/5411/44/587. diakses pada tanggal 10 April 2016 pukul 16.30 WIB.

Sanjaya, Wina. 2009. Perencanaan dan Sistem Pembelajaran. Jakarta: Kencana. 